\title{
Characterization of cerium dioxide nanoparticles prepared by supercritical water oxidation
}

\section{Hongxu Li ${ }^{\mathrm{a}, \mathrm{b}, \text { * }}$, Chao Li ${ }^{\mathrm{a}, \mathrm{b}}$, Chuanqi Jiao, ${ }^{\mathrm{a}}$ Shuai Wang ${ }^{\mathrm{b}}$}

a School of Metallurgical and Ecological Engineering, University of Science and Technology Beijing, 30\# Xueyuan Road, Beijing 100083, China

${ }^{b}$ Beijing Key Lab of Green Recycling and Extraction of Metals, University of Science and Technology Beijing, 30\# Xueyuan Road, Beijing 100083,China

\section{Correspondence information:}

Hongxu Li, Ph.D., Professor, Supervisor of PhD Candidates, Vice Dean

School of Metallurgical and Ecological Engineering, University of Science \& Technology Beijing

304\# Yejin Shengtai Building, 30\# Xueyuan Road, Beijing 100083, China

Tel: +8610 82375103,Fax: +861062332265

Mobile Tel:13611019382

E-mail: lihongxu@ustb.edu.cn, lihongxu2001@126.com

abbreviations 


\begin{abstract}
$\mathrm{CeO}_{2}$ nanoparticles with high purity and crystallinity were prepared by a continuous supercritical water oxidation (SCWO) reaction. The phase composition, microstructure, and morphology of the prepared $\mathrm{CeO}_{2}$ particles were characterized by X-Ray diffraction (XRD), field emission scanning electron microscope (FE-SEM), BET specific surface area (BET), and X-ray photoelectron spectroscopy (XPS). The size distribution of the particles is narrow with an average particle size between 10 and $13 \mathrm{~nm}$; the diameter decreased gradually as the $\mathrm{Ce}\left(\mathrm{NO}_{3}\right)_{3} \cdot 6 \mathrm{H}_{2} \mathrm{O}$ concentration in the preparation increased. The BET results show an increase in the products' specific surface area as the $\mathrm{Ce}\left(\mathrm{NO}_{3}\right)_{3} \cdot 6 \mathrm{H}_{2} \mathrm{O}$ concentration increased, with an average surface area of $48 \mathrm{~m}^{2} \cdot \mathrm{g}^{-1}$. SEM micrographs reveal that the $\mathrm{CeO}_{2}$ particles are spherical, and that higher $\mathrm{Ce}\left(\mathrm{NO}_{3}\right)_{3} \cdot 6 \mathrm{H}_{2} \mathrm{O}$ concentrations are conducive to the formation of smaller particles. However, excess $\mathrm{Ce}\left(\mathrm{NO}_{3}\right)_{3} \cdot 6 \mathrm{H}_{2} \mathrm{O}$ caused serious agglomeration, due to the higher surface energy. XPS patterns indicate that Ce(III) was almost completely oxidized to $\mathrm{Ce}(\mathrm{IV})$ in the reaction, and that the binding capacity of $\mathrm{Ce}-\mathrm{O}$ reduced gradually with increasing concentrations of $\mathrm{Ce}\left(\mathrm{NO}_{3}\right)_{3}$.
\end{abstract}

Keywords: Supercritical water oxidation, $\mathrm{CeO}_{2}$ nanoparticles, Preparation, characterization 


\section{Introduction}

Cerium is an extensively used rare-earth element with excellent redox properties. In particular, its oxide $\mathrm{CeO}_{2}$ is widely used because of its excellent oxygen storage capacity: $\mathrm{CeO}_{2}=\mathrm{CeO}_{2-\mathrm{X}}+(\mathrm{X} / 2) \mathrm{O}_{2}$. Thus, $\mathrm{CeO}_{2}$ plays an important role in different applications such as in automobile exhaust purification catalysts, fluorescent powder, electrochemical devices, ultraviolet blockers, fuel cell materials, and gas sensors. Therefore, the synthesis of $\mathrm{CeO}_{2}$ has been extensively researched [1-5].

In the last decade, many techniques for the preparation of nanoparticles were examined by researchers, including liquid-phase methods, solid-state reactions, sol-gel methods, hydrothermal synthesis, laser ablation, and co-precipitation [6-16]. Among these methods, supercritical water oxidation (SCWO) has attracted much attention in the recent years [17-22].

SCWO was first proposed by Prof. Modell [23] in the mid-1980s. The process occurs in water at temperatures and pressures above a mixture's thermodynamic critical point (for water, $\mathrm{P}_{\mathrm{c}}=22.055 \mathrm{MPa}, \mathrm{T}_{\mathrm{c}}=373.976^{\circ} \mathrm{C}$ ). Under supercritical conditions, water gains unique properties that can be used to dissolve air and oxygen or organics at an extraordinary rate. The fluid has a density between that of vapor and liquid under supercritical conditions, when phase interfaces disappear, creating a single-phase system. Studies [20] found that metal oxides have lower solubility under supercritical water conditions, thereby exhibiting relatively higher nucleation rates than under normal conditions, which is advantageous to the formation of nanoparticles. However, relatively few reports focus on the preparation of $\mathrm{CeO}_{2}$ nanoparticles by $\mathrm{SCWO}$.

SWCO is extremely complex and influenced by many factors. Slight changes in temperature or pressure can cause significant changes in the phase composition of 
products in the supercritical condition [24]. SWCO has many advantages over traditional nanopowder preparation methods, including higher efficiency, lower energy cost, environmental friendliness, and ease of control.

Many difficulties remain for the industrial application of this method. Thermodynamic data for supercritical conditions are also still lacking. The development of kinetic models of reactions at supercritical conditions in future research is necessary.

In this study, we attempted the production of nanometer-scale $\mathrm{CeO}_{2}$ powder by using a continuous SCWO reactor, and examined the reaction mechanism under supercritical water conditions by carrying out the characterization of the prepared $\mathrm{CeO}_{2}$ nanoparticles [25-27].

\section{Materials and methods}

2.1 Materials and preparation method

Transparent crystalloid $\mathrm{Ce}\left(\mathrm{NO}_{3}\right)_{3} \cdot 6 \mathrm{H}_{2} \mathrm{O}$ (above $99.0 \%$ purity, produced by Xilong Chemical Co., Ltd.) with a molecular weight of $434.24 \mathrm{~g} \cdot \mathrm{mol}^{-1}$ was used to prepare the nanoparticles. Fig. 1 shows a flowchart of the experimental process. $\mathrm{Ce}\left(\mathrm{NO}_{3}\right)_{3} \cdot 6 \mathrm{H}_{2} \mathrm{O}$ water solutions with different concentrations were prepared in a feeding cup. Then, the temperature of the reactor (described in detail below) was set to $400{ }^{\circ} \mathrm{C}$ and the reaction kettle's internal pressure was maintained at $30 \mathrm{MPa}$. After $30 \mathrm{~min}$ of reaction, the reactor was switched off and the products were allowed to cool for $10 \mathrm{~min}$ in air. The solution was collected in a beaker in a cold water bath, and the reactor was rinsed repeatedly with deionized water. The light yellow solution was allowed to rest for $2 \mathrm{~h}$. Then, the clear water was removed, and the final product was obtained by heating and drying the precipitate. 


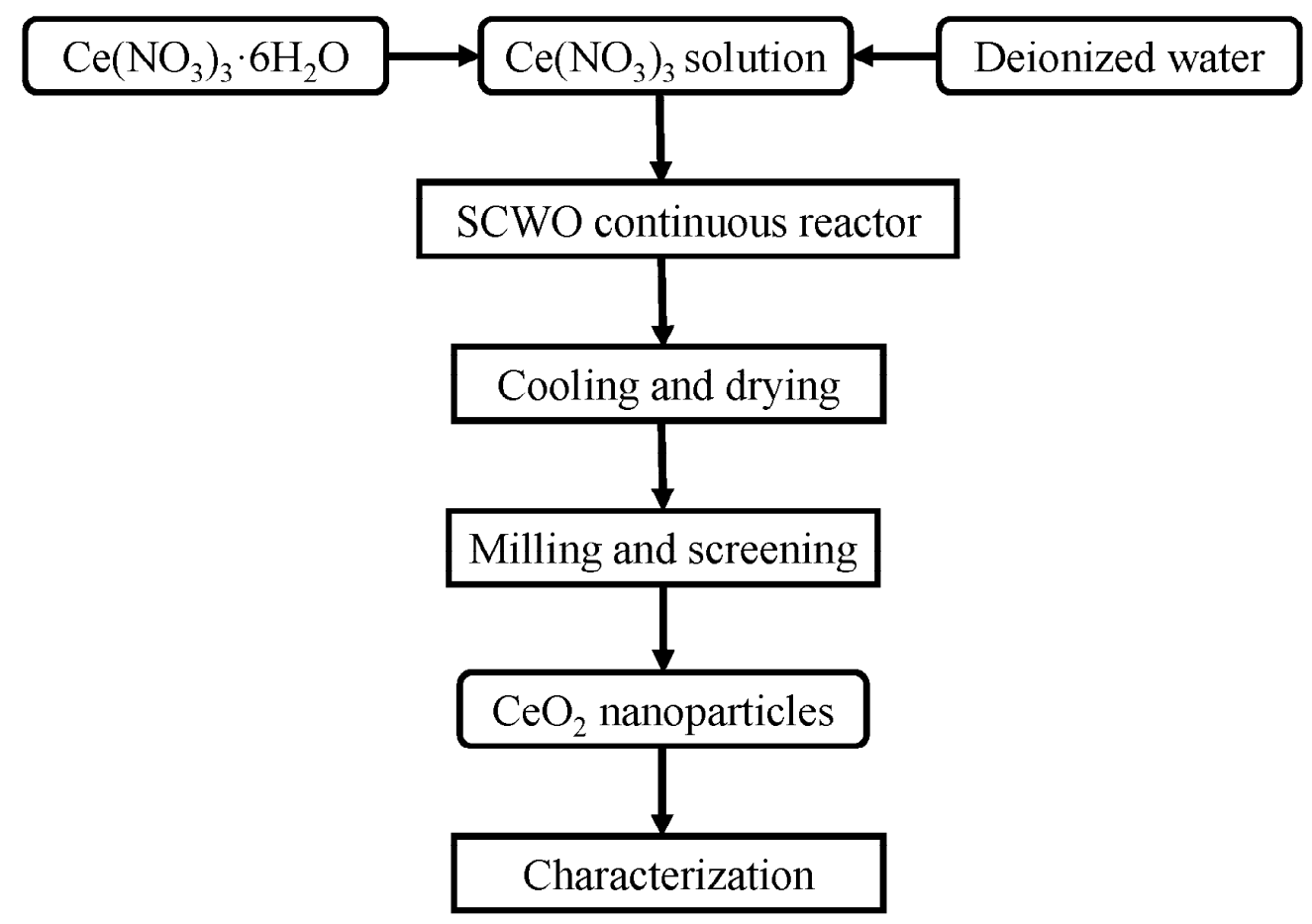

Fig. 1 Experimental process for preparing nanosized $\mathrm{CeO}_{2}$ particles

\subsection{The continuous SCWO device}

A schematic of the continuous SCWO reactor is shown in Fig. 2. All piping parts were made of $316 \mathrm{~L}$ stainless steel. The key portion of the apparatus is a tubular preheater and the tubular reactor. The piping of the reactor has a spiral structure with an inner diameter of $6 \mathrm{~mm}$. The pressure in the reactor is controlled using a back-pressure valve. An electric heating system is placed on the interlayer and can be controlled using the electric heating control cabinet, which automatically stops the heating power when the reactor temperature reaches a preset value. The liquid raw material is placed into the feeding cup via a plunger pump. When the reaction is complete, the solution is cooled by the condenser and is allowed to flow to the gas-liquid separator, from where the reaction product can be collected. 


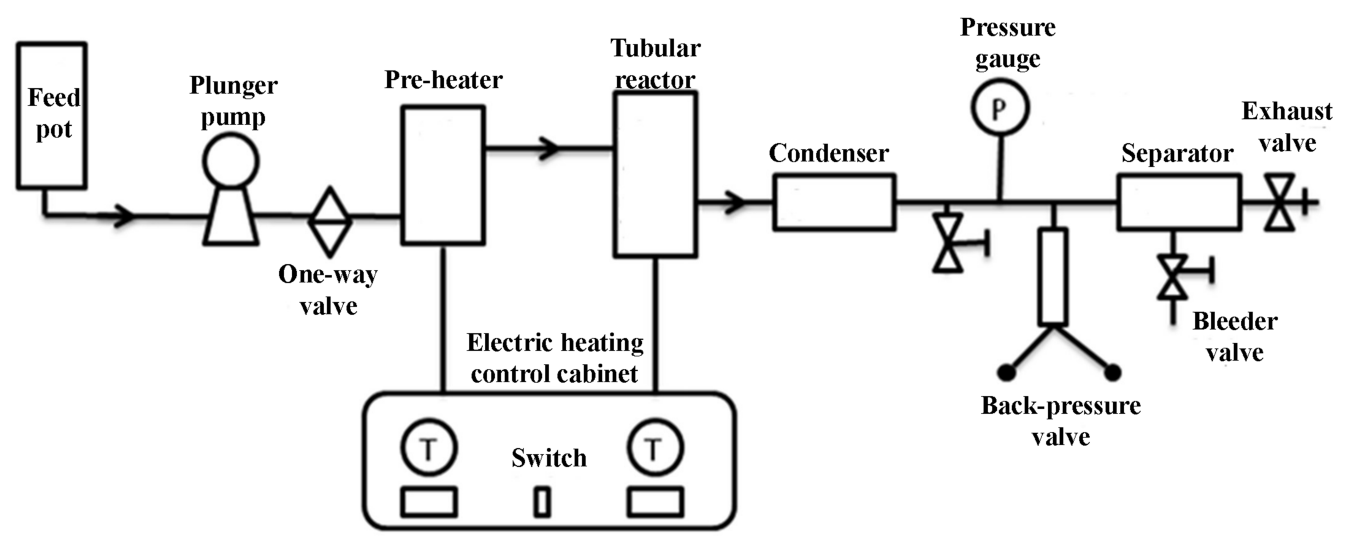

Fig. 2 Schematic of the continuous SCWO reactor

\subsection{Sample characterization}

A series of analytical methods, including XRD, FE-SEM, grading analysis, and BET, was used to characterize the phase composition, microstructure, and morphology of the experimental samples. The composition and content of the samples was tested using an X-ray fluorescence spectrometer (XRF-1800, Shimadzu Corporation), and the phase composition was determined using an X-ray diffractometer (M21XVHF22, 21KW). The element binding energy and valence states of the $\mathrm{Ce}$ and $\mathrm{O}$ species on the surface of the $\mathrm{CeO}_{2}$ nanoparticles were measured using an X-ray photoelectron spectrometer (AXIS ULTRADLD. Other methods such as FE-SEM (ZEISS SUPRA 55) and surface area analyzer were also used for the examination.

\section{Results and discussion}

\subsection{Phase composition}

The experimental products prepared using the continuous SCWO reactor with different initial $\mathrm{Ce}\left(\mathrm{NO}_{3}\right)_{3} \cdot 6 \mathrm{H}_{2} \mathrm{O}$ concentrations were tested by X-ray diffractometry, and the results are shown in Fig. 3. 


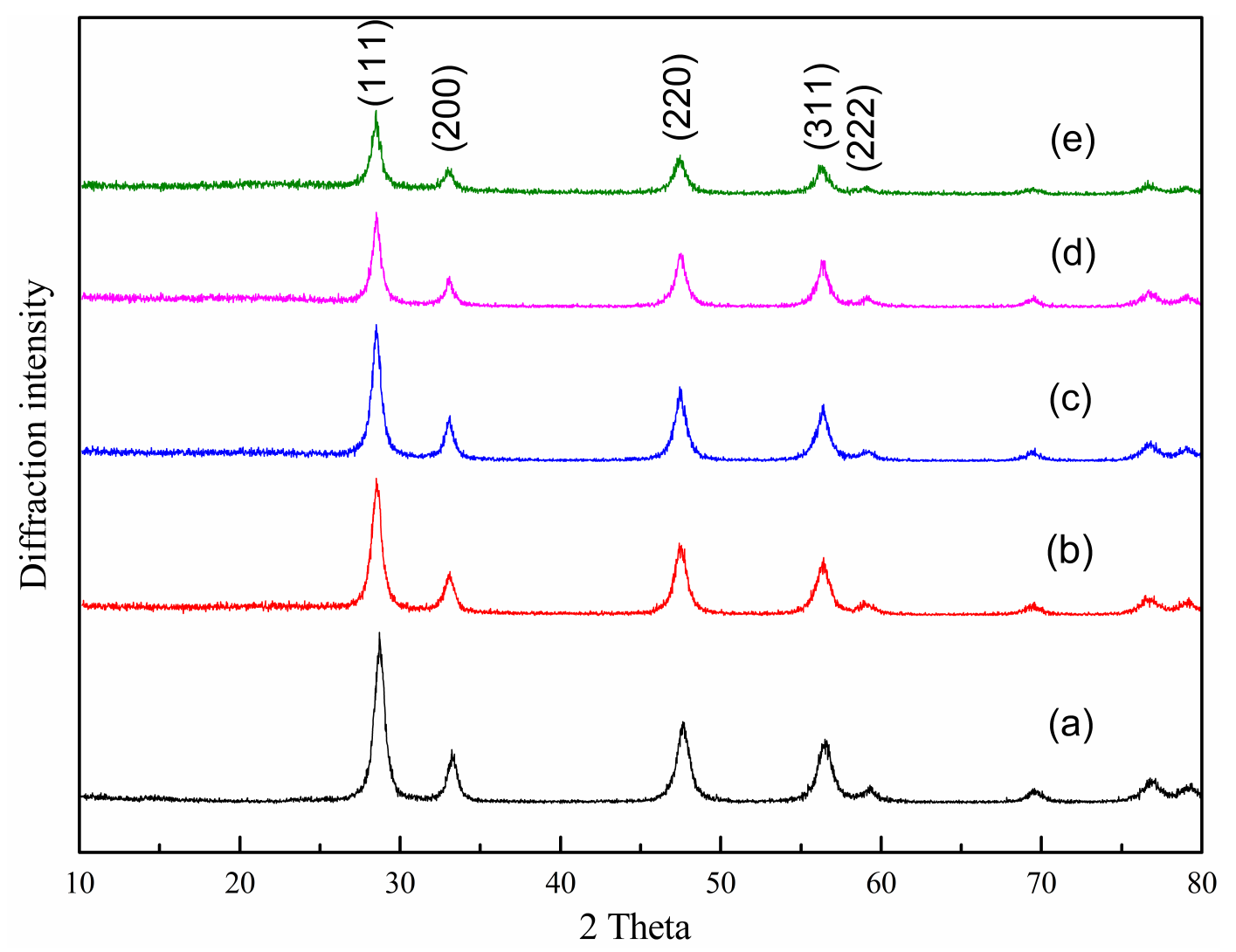

Fig. $3 \mathrm{XRD}$ patterns of $\mathrm{CeO}_{2}$ nanoparticles prepared with different $\mathrm{Ce}\left(\mathrm{NO}_{3}\right)_{3} \cdot 6 \mathrm{H}_{2} \mathrm{O}$ solution concentrations of (a) 0.10 , (b) 0.15 , (c) 0.20 , (d) 0.25 , and (e) $0.30 \mathrm{~mol} \cdot \mathrm{L}^{-1}$

The X-ray diffraction patterns display characteristic diffraction peaks of the products, corresponding well with cubic $\mathrm{CeO}_{2}$, showing that the samples are $\mathrm{CeO}_{2}$ nanoparticles with good crystallinity. By comparing the five patterns, the gradual weakening and broadening of the diffraction peak for $\mathrm{CeO}_{2}$ is visible, showing decreasing particle size of $\mathrm{CeO}_{2}$ with the increasing concentration of the $\mathrm{Ce}\left(\mathrm{NO}_{3}\right)_{3} \cdot 6 \mathrm{H}_{2} \mathrm{O}$ solution. The crystallinity of the particles deteriorates gradually with increasing $\mathrm{Ce}\left(\mathrm{NO}_{3}\right)_{3} \cdot 6 \mathrm{H}_{2} \mathrm{O}$ solution concentrations from sample (a) to (e). This observation is consistent with the inherent characteristics of nanoparticles.

The sizes of the $\mathrm{CeO}_{2}$ nanoparticles prepared in this study are under $50 \mathrm{~nm}$, within the applicable scope of the Scherrer equation. Therefore, the Scherrer equation can be 
used to describe the relationship between the X-ray diffraction peak width and the average grain size:

$$
\mathrm{D}=\mathrm{k} \lambda /(\beta \cos \theta)
$$

Where $\mathrm{D}$ is the average nanoparticle size, representing the average grain thickness perpendicular to the $(\mathrm{H}, \mathrm{K}, \mathrm{L})$ direction $(\mathrm{nm}) ; \mathrm{K}$ is constant value, $0.89 ; \lambda$ is the wavelength of the incident X-rays $(0.154056 \mathrm{~nm})$; and $\beta$ is half-breadth of the strongest X-ray diffraction peak, here means the $\mathrm{CeO}_{2}(111)$ crystal plane diffraction peak.

The average crystallite diameters $\mathrm{D}_{111}$ are $9.62,7.37,6.51,5.74$, and $3.32 \mathrm{~nm}$ for $0.10,0.15,0.20,0.25$, and $0.30 \mathrm{~mol} \cdot \mathrm{L}^{-1}$, respectively. The above calculations confirm that the $\mathrm{CeO}_{2}$ grain size decreases with increasing $\mathrm{Ce}\left(\mathrm{NO}_{3}\right)_{3} \cdot 6 \mathrm{H}_{2} \mathrm{O}$ concentration. Therefore, the use of a higher concentration of the $\mathrm{Ce}\left(\mathrm{NO}_{3}\right)_{3} \cdot 6 \mathrm{H}_{2} \mathrm{O}$ solution results in $\mathrm{CeO}_{2}$ nanoparticles with smaller grain sizes.

\subsection{Nanoparticle morphology}

FE-SEM photographs of $\mathrm{CeO}_{2}$ nanoparticles prepared by SCWO are shown in Fig. 4, while the EDS analysis results showing the Ce and $\mathrm{O}$ contents of the nanoparticles is presented in Fig. 5. The $\mathrm{CeO}_{2}$ particles are mainly spherical with sizes ranging from 5 $\mathrm{nm}$ to $25 \mathrm{~nm}$. Agglomeration gradually increased with increasing concentration of the $\mathrm{Ce}\left(\mathrm{NO}_{3}\right)_{3} \cdot 6 \mathrm{H}_{2} \mathrm{O}$ solution and the agglomerated nanoparticles changed from soft to rigid. 

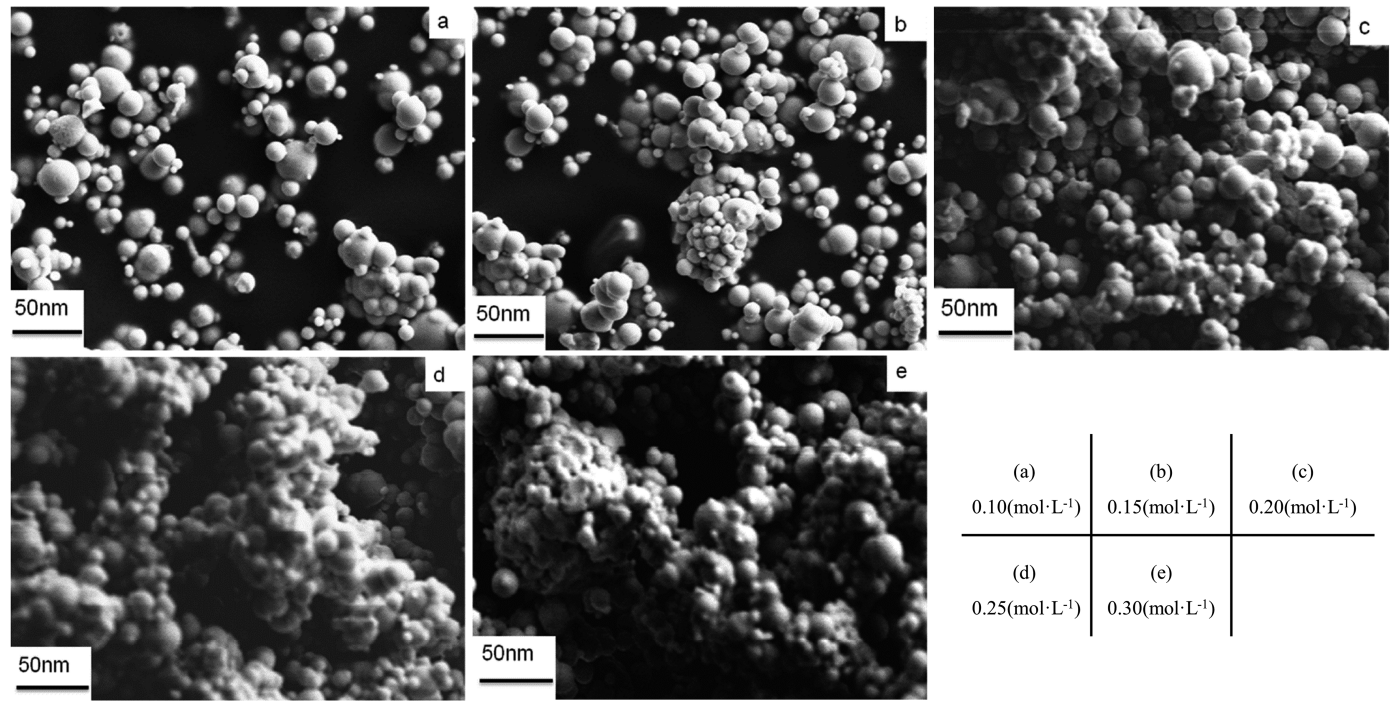

Fig. 4 FE-SEM photographs of $\mathrm{CeO}_{2}$ nanoparticles prepared by SCWO with different $\mathrm{Ce}\left(\mathrm{NO}_{3}\right)_{3} \cdot 6 \mathrm{H}_{2} \mathrm{O}$ solution concentrations of (a) 0.10 , (b) 0.15 , (c) 0.20 , (d) 0.25 , and (e)

\section{$0.30 \mathrm{~mol} \cdot \mathrm{L}^{-1}$}


Fig. 5 FE-SEM photograph and an EDS qualitative analysis map of $\mathrm{CeO}_{2}$ nanoparticles

$$
\text { prepared with } 0.20 \mathrm{~mol} \cdot \mathrm{L}^{-1} \mathrm{Ce}\left(\mathrm{NO}_{3}\right)_{3} \cdot 6 \mathrm{H}_{2} \mathrm{O} \text { solution }
$$

The supercritical water environment is conducive to the formation of nanoscale particles, but the small particles agglomerate readily with adjacent grains to minimize surface energy. In this experiment, more $\mathrm{CeO}_{2}$ crystal nuclei are formed as the concentration of the solution increases. Therefore, crystals are affected in their growth by the nuclei around them. This explains why high concentrations of $\mathrm{Ce}\left(\mathrm{NO}_{3}\right)_{3}$ are disadvantageous to the synthesis of nanometer-scale $\mathrm{CeO}_{2}$ powder with good dispersity.

3.3 Analysis of particle size and specific surface area 
The $\mathrm{CeO}_{2}$ nanoparticles were analyzed by using related size-distribution Digital Micrograph software (Fig. 6). The size of $\operatorname{most} \mathrm{CeO}_{2}$ nanoparticles is in the range of 5$15 \mathrm{~nm}$. The particles of samples produced with high $\mathrm{Ce}\left(\mathrm{NO}_{3}\right)_{3}$ concentrations are small; the actual particle diameters exceed those calculated from XRD data (Table 1).


Fig. 6 Average particle size distribution histogram of $\mathrm{CeO}_{2}$ nanoparticles prepared using the continuous SCWO reactor with $\mathrm{Ce}\left(\mathrm{NO}_{3}\right)_{3} \cdot 6 \mathrm{H}_{2} \mathrm{O}$ solution concentrations of (a) 0.10 , (b) 0.15 , (c) 0.20 , (d) 0.25 , and (e) $0.30 \mathrm{~mol} \cdot \mathrm{L}^{-1}$

Table 1. Statistics of $\mathrm{CeO}_{2}$ particle sizes from FE-SEM map

\begin{tabular}{|c|c|c|c|c|c|}
\hline \multirow{2}{*}{ Sample } & \multirow{2}{*}{$\begin{array}{l}\mathrm{C}_{\mathrm{Ce}(\mathrm{NO} 3) 3} \\
/ \mathrm{mol} \mathrm{L}^{-1}\end{array}$} & \multirow{2}{*}{$\begin{array}{l}\text { Sample } \\
\text { size/pcs }\end{array}$} & \multicolumn{2}{|c|}{ Grain size/nm } & \multirow[b]{2}{*}{ Average } \\
\hline & & & Maximum & Minimum & \\
\hline $\mathrm{a}$ & 0.10 & 153 & 35.06 & 3.11 & 12.58 \\
\hline $\mathrm{b}$ & 0.15 & 235 & 30.41 & 2.42 & 11.32 \\
\hline $\mathrm{c}$ & 0.20 & 203 & 31.52 & 2.34 & 12.64 \\
\hline d & 0.25 & 140 & 29.11 & 2.69 & 10.59 \\
\hline $\mathrm{e}$ & 0.30 & 195 & 30.08 & 3.12 & 10.99 \\
\hline
\end{tabular}


The prepared $\mathrm{CeO}_{2}$ samples have pore-free spherical morphology. Fig. 7 shows the nitrogen adsorption-desorption curve of the $\mathrm{CeO}_{2}$ nanoparticles prepared with 0.20 $\mathrm{mol} \cdot \mathrm{L}^{-1} \mathrm{Ce}\left(\mathrm{NO}_{3}\right)_{3} \cdot 6 \mathrm{H}_{2} \mathrm{O}$ aqueous solution; the multipoint BET specific surface area for this sample is calculated to be $45.5 \mathrm{~m}^{2} \cdot \mathrm{g}^{-1}$. The results of the multipoint BET analysis are shown in Table 2. The average specific surface area is $48 \mathrm{~m}^{2} \cdot \mathrm{g}^{-1}$.

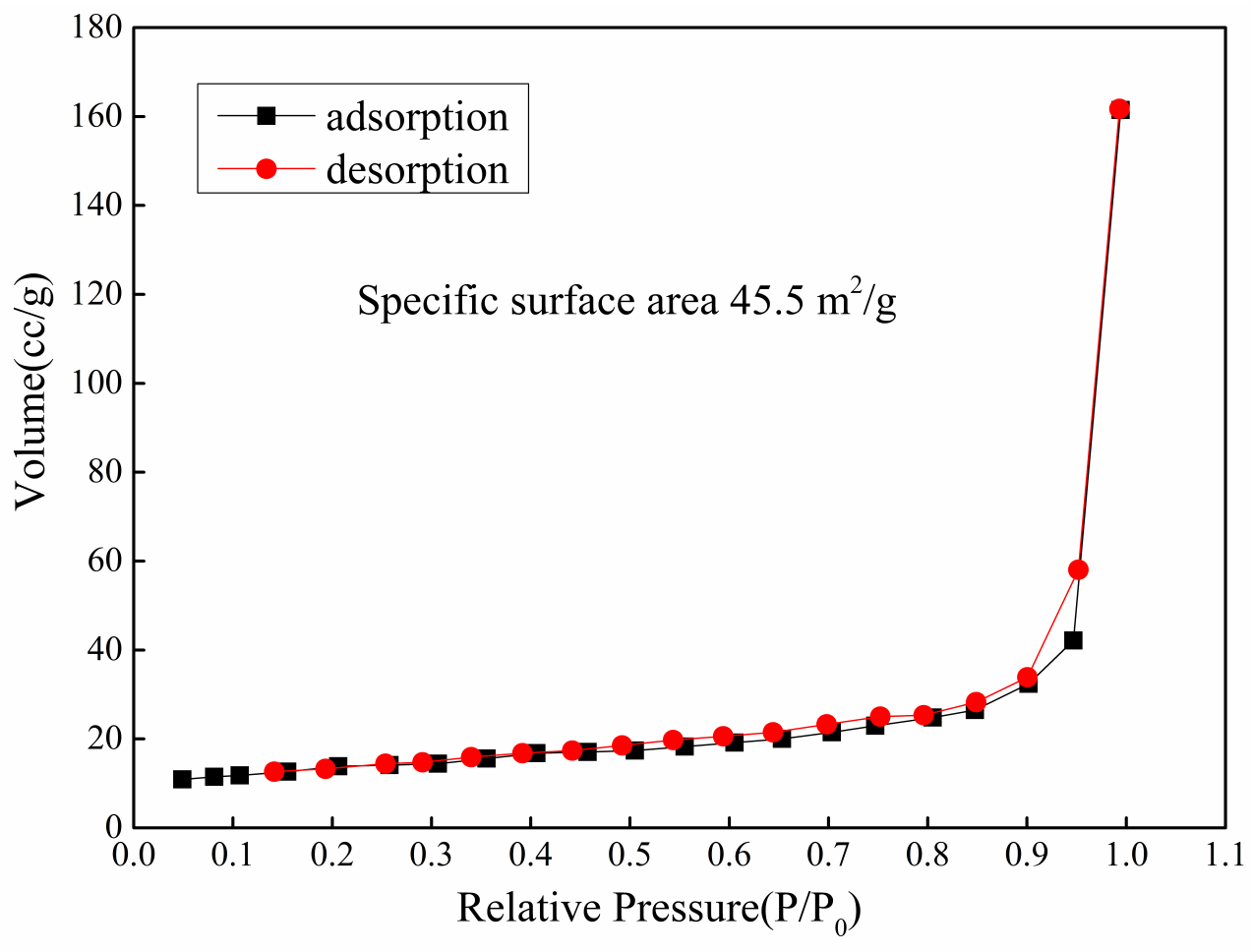

Fig.7 Adsorption-desorption curves of $\mathrm{CeO}_{2}$ nanoparticles prepared using $0.20 \mathrm{~mol} \cdot \mathrm{L}^{-1}$ $\mathrm{Ce}\left(\mathrm{NO}_{3}\right)_{3} \cdot 6 \mathrm{H}_{2} \mathrm{O}$ solution

Table 2. Specific surface area of $\mathrm{CeO}_{2}$ nanoparticles

\begin{tabular}{cc}
\hline $\mathrm{C}_{\mathrm{Ce}(\mathrm{NO} 3) 3} / \mathrm{mol} \cdot \mathrm{L}^{-1}$ & specific surface area $/ \mathrm{m}^{2} \cdot \mathrm{g}^{-1}$ \\
\hline 0.10 & 40.2 \\
0.15 & 40.9 \\
0.20 & 45.5 \\
0.25 & 55.1 \\
0.30 & 58.3 \\
\hline
\end{tabular}




\subsection{XPS analysis}

Cerium is a variable-valence element with main oxidation states of +3 and +4 . X-ray photoelectron spectroscopy (XPS) was used to analyze ion valency and the binding energy of cerium (Fig. 8). Sharp peaks from the inner energy levels, such as $\mathrm{Ce}\left(4 \mathrm{~d}_{5 / 2}\right)$, $\mathrm{Ce}\left(4 \mathrm{~d}_{3 / 2}\right), \mathrm{C}(1 \mathrm{~s}), \mathrm{O}(1 \mathrm{~s}), \mathrm{Ce}\left(3 \mathrm{~d}_{5 / 2}\right)$, and $\mathrm{Ce}\left(3 \mathrm{~d}_{3 / 2}\right)$, can be easily identified. The $\mathrm{C}(1 \mathrm{~s})$ peak is used for calibration.

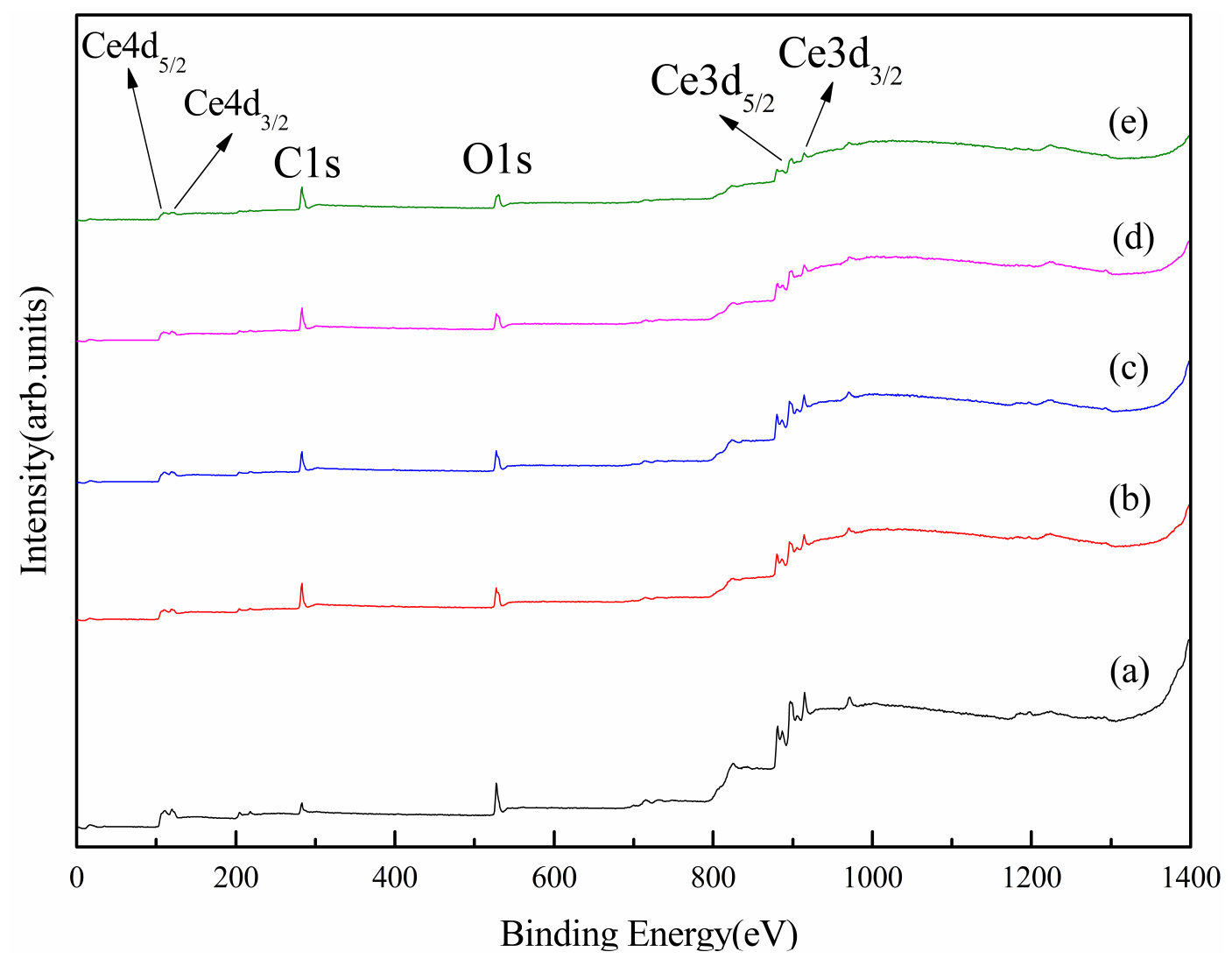

Figure. 8 X-ray photoelectron spectrum of $\mathrm{CeO}_{2}$ nanoparticles prepared using the continuous SCWO reactor with $\mathrm{Ce}\left(\mathrm{NO}_{3}\right)_{3} \cdot 6 \mathrm{H}_{2} \mathrm{O}$ solution concentrations of (a) 0.10 , (b)

$$
0.15 \text {, (c) } 0.20 \text {, (d) } 0.25 \text {, and (e) } 0.30 \mathrm{~mol} \cdot \mathrm{L}^{-1}
$$

As shown in the samples' spectra (Fig. 8), both lattice peak $O(1)$ and adsorbed oxygen peak $\mathrm{O}(2)$ shift gradually to lower binding energies. The lattice oxygen peak $\mathrm{O}(1)$ corresponds to the binding energy of $\mathrm{Ce}-\mathrm{O}$, while the generation of the adsorbed 
oxygen peak $\mathrm{O}(2)$ may be due to the coaction between oxygen vacancies and hydroxyl groups on the samples' surfaces. The peak area ratio of $\mathrm{O}(2)$ to $\mathrm{O}(1 \mathrm{~s})$ gradually increases from sample (a) to (e) as shown in Fig. 9, indicating the weakened binding capacity of $\mathrm{Ce}$ and $\mathrm{O}$ and the gradual decrease in the relative concentrations of $\mathrm{O}$ species. Possibly, as the concentration of $\mathrm{Ce}\left(\mathrm{NO}_{3}\right)_{3}$ increases, the decrease in $\mathrm{O}$ species concentration leads to oxygen vacancies.



Fig. 9 XPS map of the $\mathrm{O}(1 \mathrm{~s})$ peak of $\mathrm{CeO}_{2}$ nanoparticles prepared with $\mathrm{Ce}\left(\mathrm{NO}_{3}\right)_{3} \cdot 6 \mathrm{H}_{2} \mathrm{O}$ solution concentrations of (a) 0.10 , (b) 0.15 , (c) 0.20 , (d) 0.25 , and (e)

$$
0.30 \mathrm{~mol} \cdot \mathrm{L}^{-1}
$$

The six electron binding energy peaks in the range of $888-916 \mathrm{eV}$ are the characteristic peaks of $\mathrm{Ce}(\mathrm{IV})$, and $\mathrm{Ce}\left(3 \mathrm{~d}_{5 / 2}\right)$ and $\mathrm{Ce}\left(3 \mathrm{~d}_{3 / 2}\right)$ both display three peaks: in Fig. 10 these are labeled $\mathrm{W}_{1}, \mathrm{~W}_{2}$, and $\mathrm{W}_{3}$, and $\mathrm{T}_{1}, \mathrm{~T}_{2}$, and $\mathrm{T}_{3}$, respectively. This shows that $\mathrm{Ce}(\mathrm{III})$ almost completely oxidized to $\mathrm{Ce}(\mathrm{IV})$. 


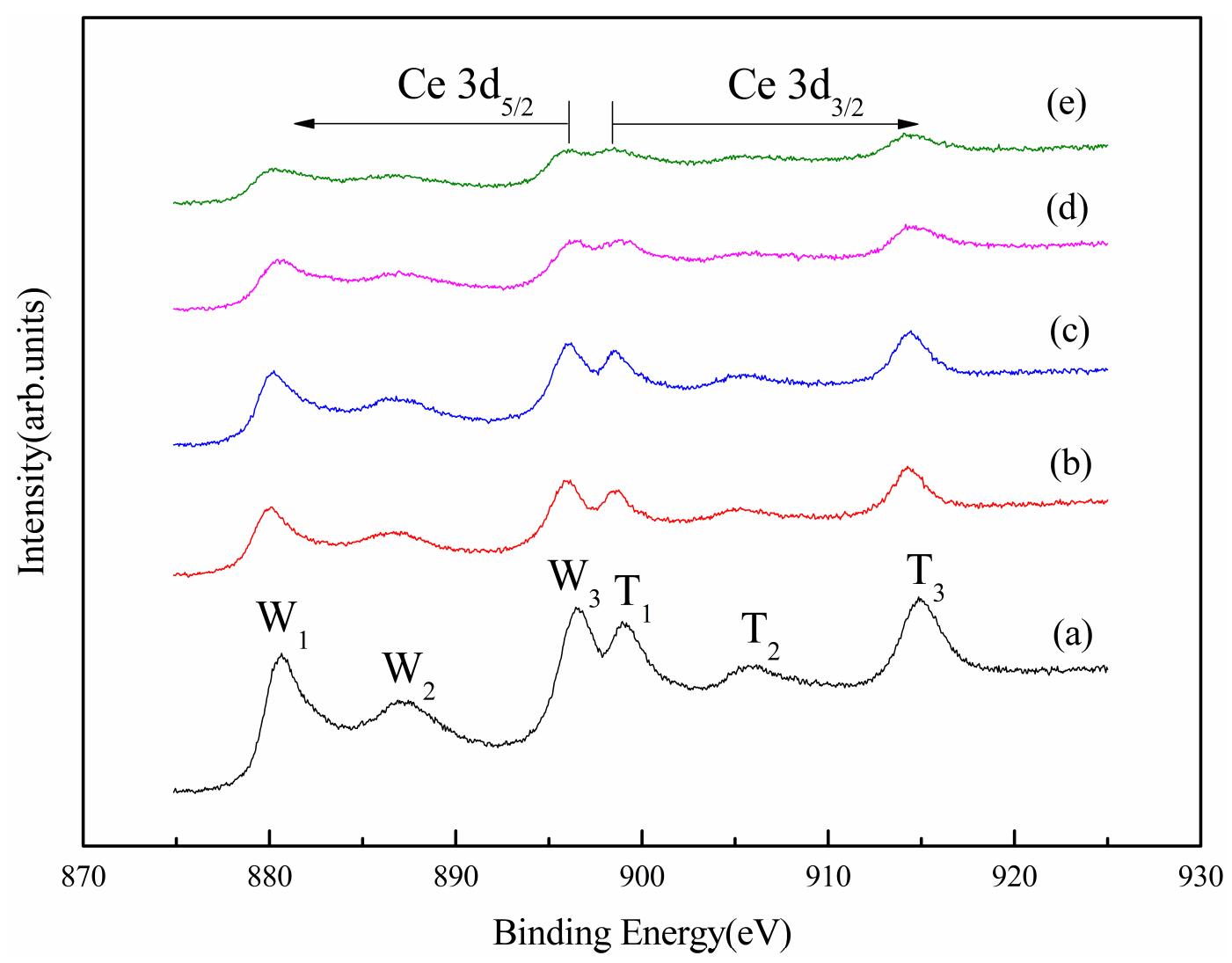

Fig. 10 XPS fine-scanning map of the $\mathrm{Ce}(3 \mathrm{~d})$ peaks of $\mathrm{CeO}_{2}$ nanoparticles prepared with $\mathrm{Ce}\left(\mathrm{NO}_{3}\right)_{3} \cdot 6 \mathrm{H}_{2} \mathrm{O}$ solution concentrations of (a) 0.10 , (b) 0.15 , (c) 0.20 , (d) 0.25 , and (e) $0.30 \mathrm{~mol} \cdot \mathrm{L}^{-1}$

The energy intervals of the $\mathrm{Ce}\left(3 \mathrm{~d}_{5 / 2}\right)$ and $\mathrm{Ce}\left(3 \mathrm{~d}_{3 / 2}\right)$ main peaks are approximately 19 $\mathrm{eV}$, which remain constant for all samples, showing that the Ce(IV) oxidation state maintains prevalence with increasing $\mathrm{Ce}\left(\mathrm{NO}_{3}\right)_{3} \cdot 6 \mathrm{H}_{2} \mathrm{O}$ concentrations.

Peak strength and area both gradually reduce from sample (a) to (e), showing that the binding capacity gradually declines, leading to the occurrence of oxygen vacancies. Cerium showed only the +4 oxidation state in this experiment, but an excess of oxygen vacancies may lead to the collapse of the $\mathrm{CeO}_{2}$ cubic structure, thereby shifting cerium's valence state from +4 to lower levels. 
Some researchers [28] suggest that high concentrations of $\mathrm{H}^{+}$and $\mathrm{OH}^{-}$exist in supercritical water and that $\mathrm{OH}^{-}$participates in the generation of nanoparticles; therefore, metal nitrate solutions react as below (Me represents a metallic element):

The first step is the hydrolysis reaction:

$$
\mathrm{Me}\left(\mathrm{NO}_{3}\right)_{\mathrm{x}}+\mathrm{xH}_{2} \mathrm{O}=\mathrm{Me}(\mathrm{OH})_{\mathrm{x}}+\mathrm{xHNO}_{3}
$$

The second step is the dehydration reaction:

$$
\mathrm{Me}(\mathrm{OH})_{\mathrm{x}}=\mathrm{MeO}_{\mathrm{x} / 2}+\mathrm{x} / 2 \mathrm{H}_{2} \mathrm{O}
$$

This theory cannot explain the production of $\mathrm{CeO}_{2}$ in this study because of the hydrolysis of $\mathrm{Ce}\left(\mathrm{NO}_{3}\right)_{3}$ rather than $\mathrm{CeO}_{3 / 2}$. This means that a redox reaction occurred in the reactor with the oxidation product of red-brown gaseous $\mathrm{NO}_{2}$, which was observed in the synthesis process.

\subsection{Discussion of supercritical water crystallization theory}

The crystal growth process can be divided into three steps:

(1) Diffusion: the solute from the bulk solution passes through the stationary liquid layer on the crystal surface, and transfers to the crystal surface.

(2) Surface reaction: the crystal surface is formed and the heat of crystallization is released.

(3) The heat gets transferred to the solution by conduction.

Compared with ordinary hydrothermal synthesis methods, the self-diffusion coefficient of supercritical water is many times higher than that of liquid water, thus decreasing hydrogen bonding between water molecules and greatly reducing molecular polarity. The diffusion velocity in crystal nucleation and growth is so rapid that it results in excessively large grains. 
In this experiment, the water solution of $\mathrm{Ce}\left(\mathrm{NO}_{3}\right)_{3} \cdot 6 \mathrm{H}_{2} \mathrm{O}$ quickly reached the supercritical condition from room temperature and normal pressures, so a high supersaturation degree was obtained and many $\mathrm{CeO}_{2}$ crystal nuclei were formed spontaneously.

The common mathematic formula determining crystal growth rate is as follows:

$$
\mathrm{G}=\mathrm{K}_{\mathrm{g}} \cdot \Delta \mathrm{C}^{\mathrm{g}}
$$

Where $\mathrm{G}$ is crystal growth rate, $\mathrm{m}^{-3} \cdot \mathrm{s}^{-1} ; \mathrm{K}_{\mathrm{g}}$ is crystal growth rate constant; $\Delta \mathrm{C}$ is degree of supersaturation, $\mathrm{mol} / \mathrm{L}$; $\mathrm{g}$ is kinetic power exponent in the process of the nucleation, dimensionless.

The degree of supersaturation drives the formation of crystal nuclei and their subsequent growth. As shown in Eq. (4), greater supersaturation leads to a higher nucleation rate.

The advantage of preparing nanoparticles by SWCO depends on the rapid decrease in the dielectric constant of water and the rapid hydrolysis of $\mathrm{Ce}\left(\mathrm{NO}_{3}\right)_{3}$ under supercritical conditions. Therefore, the solubility of the bulk solution was low, which could result in a high degree of supersaturation in a short time, corresponding to a high nucleation rate that promotes nanoparticle formation.

For crystallization products with uniform particle size and distribution, the crystal nucleation rate must be controlled.

Compared with subcritical and general water systems, the crystal growth rate and nucleation rate by SWCO were higher because of the high supersaturation degree of $\mathrm{Ce}\left(\mathrm{NO}_{3}\right)_{3}$. The ratio between these rates was relatively small; thus, the obtained crystals were small in size but had non-uniform shapes. 
Therefore, to prepare particles with satisfactory size and uniformity, the crystal nucleation and growth rates should be controlled by manipulating the temperature, pressure, cooling rate, and other factors affecting the reaction.

\section{Conclusions}

The microstructure and morphology of $\mathrm{CeO}_{2}$ nanoparticles prepared by SWCO were examined and analyzed. Results indicate that the fabricated $\mathrm{CeO}_{2}$ nanoparticles are mainly spherical with good crystallinity. The average particle size of the $\mathrm{CeO}_{2}$ nanoparticles ranged from 10 to $13 \mathrm{~nm}$. Suitable particle sizes and uniform size distributions can be achieved by controlling the temperature, pressure, raw material concentration, and cooling conditions in the fabrication process.

\section{ACKNOWLEDGMENT}

The authors gratefully acknowledge the financial support of the National Science Foundation of PRC for the Research Project [51234008] and of Beijing technical development project [00012132].

\section{References:}

[1]. Khan, S.B., et al., Exploration of $\mathrm{CeO} 2$ nanoparticles as a chemi-sensor and photo-catalyst for environmental applications. Science of The Total Environment, 2011. 409(15): p. 2987-2992.

[2]. Faria, P.C.C., et al., Cerium, manganese and cobalt oxides as catalysts for the ozonation of selected organic compounds. Chemosphere, 2009. 74(6): p. 818-824.

[3]. Raemy, D.O., et al., Cerium oxide nanoparticle uptake kinetics from the gasphase into lung cells in vitro is transport limited. European Journal of Pharmaceutics 
and Biopharmaceutics, 2011. 77(3): p. 368-375.

[4]. Ashraf, P.M. and S.M.A. Shibli, Development of cerium oxide and nickel oxideincorporated aluminium matrix for marine applications. Journal of Alloys and Compounds, 2009. 484(1- 2): p. 477-482.

[5]. Jr. Barbier, J., et al., Catalytic wet air oxidation of ammonia over $\mathrm{M} / \mathrm{CeO} 2$ catalysts in the treatment of nitrogen-containing pollutants . Catalysis Today, 2002. 75(1-4): p. 29- 34.

[6]. Izu, N., W. Shin and N. Murayama, Fast response of resistive-type oxygen gas sensors based on nano-sized ceria powder. Sensors and Actuators B: Chemical, 2003. 93(1- 3): p. 449-453.

[7]. Yadav, T.P. and O.N. Srivastava, Synthesis of nanocrystalline cerium oxide by high energy ball milling. Ceramics International, 2012. 38(7): p. 5783-5789.

[8]. Mahmoud, W.E. and A. Faidah, Microwave assisted hydrothermal synthesis of engineered cerium oxide nanopowders. Journal of the European Ceramic Society, 2012. 32(13): p. 3537-3541.

[9]. Nagy, K. and I. Dékány, Preparation of nanosize cerium oxide particles in $\mathrm{W} / \mathrm{O}$ microemulsions. Colloids and Surfaces A: Physicochemical and Engineering Aspects, 2009. 345(1- 3): p. 31-40.

[10]. Wei, J., et al., Formation of catalytically active $\mathrm{CeO} 2$ hollow nanoparticles guided by oriented attachment. Materials Letters, 2012. 84(0): p. 77-80.

[11]. Balavi, H., et al., Preparation and optimization of $\mathrm{CeO} 2$ nanoparticles and its application in photocatalytic degradation of Reactive Orange 16 dye. Powder Technology, 2013. 249(0): p. 549-555.

[12]. Walton, R.I., Solvothermal synthesis of cerium oxides. Progress in Crystal 
Growth and Characterization of Materials, 2011. 57(4): p. 93-108.

[13]. Chen, H. and H. Chang, Synthesis of nanocrystalline cerium oxide particles by the precipitation method. Ceramics International, 2005. 31(6): p. 795-802.

[14]. Jiang, D., et al., Preparation and evaluation of $\mathrm{MnOx}-\mathrm{CeO} 2$ nanospheres via a green route. Catalysis Communications, 2012. 17(0): p. 59-63.

[15]. Pinjari, D.V. and A.B. Pandit, Room temperature synthesis of crystalline $\mathrm{CeO} 2$ nanopowder: Advantage of sonochemical method over conventional method. Ultrasonics Sonochemistry, 2011. 18(5): p. 1118-1123.

[16]. Grujić-Brojčin, M., et al., Surface modification of sol- gel synthesized TiO2 nanoparticles induced by La-doping. 2014. p. 30-41.

[17]. Reverchon, E. and R. Adami, Nanomaterials and supercritical fluids. The Journal of Supercritical Fluids, 2006. 37(1): p. 1- 22.

[18]. Veriansyah, B., et al., Characterization of surface-modified ceria oxide nanoparticles synthesized continuously in supercritical methanol. The Journal of Supercritical Fluids, 2009. 50(3): p. 283-291.

[19]. Rangappa, D., et al., Synthesis, characterization and organic modification of copper manganese oxide nanocrystals under supercritical water. The Journal of Supercritical Fluids, 2008. 44(3): p. 441-445.

[20]. Choi, H., et al., Continuous synthesis of metal nanoparticles in supercritical methanol. The Journal of Supercritical Fluids, 2010. 52(3): p. 285-291.

[21]. Slostowski, C., et al., Synthesis of cerium oxide-based nanostructures in nearand supercritical fluids. The Journal of Supercritical Fluids, 2013. 84(0): p. 89-97.

[22]. Byrappa, K., S. Ohara and T. Adschiri, Nanoparticles synthesis using supercritical fluid technology - towards biomedical applications. Advanced Drug 
Delivery Reviews, 2008. 60(3): p. 299-327.

[23]. Modell, M., Processing methods for the oxidation of organics in supercritical water. 1982, U.S. Patent No. 4,338,199.

[24]. Rich, R., Inorganic Reactions in Water. 2010: springer. 63-73.

[25]. Wang, M., et al., Low temperature preparation and characterization of $\mathrm{TiO} 2$ nanoparticles coated glass beads by heterogeneous nucleation method. Materials Characterization, 2013. 76: p. 39-47.

[26]. Pal, J. and P. Chauhan, Structural and optical characterization of tin dioxide nanoparticles prepared by a surfactant mediated method. Materials Characterization, 2009. 60(12): p. 1512-1516.

[27]. Song, M., M. Chen and Z. Zhang, Preparation and characterization of Mg nanoparticles. Materials Characterization, 2008. 59(5): p. 514-518.

[28]. Adschiri, T., K. Kanazawa and K. Arai, Rapid and continuous hydrothermal crystallization of metal oxide particles in supercritical water. Journal of the American Ceramic Society, 1992. 75(4): p. 1019-1022. 